\title{
Redefining the Role of Teachers in the Digital Era
}

\author{
Dr Jayendrakumar N. Amin ${ }^{1 *}$
}

\section{ABSTRACT}

This paper deals with key roles required for a teacher in new digital era. Teachers' role in the 21st century has become more complex in the present changing world here knowledge is almost unlimited. Teachers are expected to become technologically oriented and responsible not only for their teaching but also for their students' learning. Today teachers are required to be facilitators helping learners to make judgements about the quality and validity of new sources and knowledge, be open-minded and critical independent professionals, be active co-operators, collaborators, and mediators between learners and what they need to know, and providers to scaffold understanding. In this digital era, teachers' role has shifted from mere preacher to the manager of students social and emotions behaviours; mentor for their learning and over-all development as a balanced citizen; motivator for slow learner and a fast learner in digital environment. He has to keep watch on the time spent by learners for their proper time management which make certain that the learner utilize optimum e-resources. He has to address social and emotional issues that affect learners' learning, and be ready to make changes when their learning stalls.

Keywords: Teachers' Role, Digital Era, Technologies, Educational Changes.

There is a global concern that our educational systems are obsolete and failing to promote the necessary skills that can adequately prepare our children for the future. The earlier generations' drive to study was robustly rooted in conscientiousness. The new generations have different motivational profiles: in their lives interest, emotions, and engagement matter much more. Teachers' role in the $21^{\text {st }}$ century has become more complex in the present changing world; here knowledge is almost unlimited. Teachers are expected to become technologically oriented and responsible not only for their teaching but also for their students' learning. They have to cater for particular needs of individual students in heterogeneous classes, and create a student-centered learning environment which endeavors for excellence, and offers opportunities for enquiry and dynamic learning. Teachers need to meet the standards of the curriculum while enhancing students' creativity, curiosity and motivation. They need to ensure a safe ambience in their

\footnotetext{
${ }^{1}$ Associate professor, M.Ed. College, Vadu

*Responding Author

(c) 2016 I J Amin; licensee IJIP. This is an Open Access Research distributed under the terms of the Creative Commons Attribution License (http://creativecommons.org/licenses/by/2.0), which permits unrestricted use, distribution, and reproduction in any Medium, provided the original work is properly cited.
} 


\section{Redefining the Role of Teachers in the Digital Era}

classrooms and maintain relationships with students, parents and staff. However, the question of how to push in technological changes in education without posing a risk to human values remains unresolved.

Higher education institutions face a number of opportunities and challenges as the result of the digital revolution. This is because higher education institutions perform a number of scholarship functions including teaching and research which are affected by the availability and usage of digital technologies (Weller and Anderson 2013). In the new digital and knowledge society in the 21st century, education is facing great challenges from traditional ways of learning towards innovative ways of learning. It also raises great demands for the transformation of teacher roles from the traditional knowledge transmitter to a new set of roles such as facilitator and coordinator. This transformation requires that teachers can face their new tasks in a more flexible way and be prepared for their new roles.

The role of teachers has changed and continues to change from being an instructor to becoming a constructor, facilitator, coach, and creator of learning environments. Today teachers are required to be facilitators helping learners to make judgements about the quality and validity of new sources and knowledge, be open-minded and critical independent professionals, be active cooperators, collaborators, and mediators between learners and what they need to know, and providers to scaffold understanding (Weinberger, Fischer, \& Mandl, 2002).

The world has become more complicated, competitive and intertwined. In order for individuals to survive and thrive in the era of globalization and digitalization, people should equip with problem-solving skills, creative mindset and information literacy. Conventional teaching is not able to educate adequate citizen to live in the 21st century. Therefore, a person needs to develop his/her skills and knowledge constantly due to persistent change in every aspects of the society. However, the beliefs and practices of teaching have to transform from old-way thinking first before teachers can influence students' thinking and learning critically. With a simple click to access countless information and resources, the role of teachers as authoritative single provider of knowledge and skills has been challenged by readily available information technology.

If information and resources are easily findable and accessible, we may wonder the necessity of teachers' existence in the coming future. However, the arguable question is not if teachers will be replaced but what role teachers should play in helping themselves and students adjust to social changes. Undoubtedly, the one and only job of teachers to instil factual knowledge into students is not feasible anymore and is questionable in the current society. The society has developed a variety of roles for teachers to function and practice in the connected age. Everyone's expectation toward teaching and learning shifted dramatically to emphasize the impact of social and technological network on education. Earlier on, I was uncertain on if teachers are not content experts or subject experts to provide students with ultimate knowledge, will students continue to respect teachers or why would they listen to a person if they can find what they need by 


\section{Redefining the Role of Teachers in the Digital Era}

googling? I think I got my answer through defining the role of teachers in networked learning. In my opinion, the value of teachers is not through lecturing but through guiding and facilitating students to become self-directed learners.

While the introduction of Information and Communication Technology (ICT) and other digital technologies in some higher institutions of learning has yielded positive results, the birth of interactive learning has called into question the acceptance of such teaching tools and the new roles that teachers have to play ( $\mathrm{Lu}$ J, Lu C, Yu CS, \& Yao JE; 2014). The role of teachers has transferred to a more broad and diverse definition to meet the needs of learning communities. I think the way of how teachers view or interact with students is changing as well. In a diverse society, teachers should view each student as an individual and facilitate learning based on personal interests. It's the diversity and individualization that make the world unique and special. Even though it sounds difficult but it is not impossible. The rising question is how teachers know all kinds of knowledge and skills to teach every student with different talent? As a result, this is where networked learning comes into play.

Lentell (2003) states that academics have to be knowledge experts, effective listeners and communicators as well as coaches, facilitators, mentors, problem solvers, designers, supporters and resource co-ordinators. As an effective teacher in the digital era, he/she has to know where to find relevant information, how to solve problems and what to keep up learning. General speaking, a teacher has to improve teaching methods and develop professional learning continually along with new developments. Hence, teachers in the $21^{\text {st }}$ century have to comprehend that change is inevitable and must accept and prepare for growth. Most essentially, learning from networks related to professional developments or personal interests put away teachers' time-consuming efforts and prepare them with rationality when change happens. If the teacher employs digital resources judiciously, he can create a digitalized environment having the following effects on teaching learning process:

\section{Basic effects of digitalized environment on the teaching-learning process:}

- Has an improving effect in terms of quality of student work and practical examples through visualisation;

- Improves poor handwriting and languages skills through word processing;

- Facilitates self-pacing with increased capacities to deal with individual learning styles as students can work at the pace and intensity suitable to their needs;

- Enables collaborative learning with little indication of the isolated learner;

- Encourages use of peer coaching and peer reviews;

- Develops communication skills and awareness of different audiences;

- Has impact on resource-based learning and access to real world information through the Web; 


\section{Redefining the Role of Teachers in the Digital Era}

- Enhances information consistency and accuracy adding to authenticity of learning tasks, with pragmatic and advanced information;

- Augments learner motivation through practical activity, visual demonstrations and improved modes of presentation;

- Promotes independent learning and individual preferences for process, outline, method and design;

- Furnishes learners more control;

- Lets learners to produce high quality multimedia products;

- Transforms teacher practices, planning tools and assessment rubrics;

- Boosts opportunities for classes to advance and for learner experiences to shape results;

- Can inspire students to be committed to learning and to contribute in learning activities;

- Can develop students' higher-order thinking: their ability to apply knowledge and skills to analyze challenging problems, grasp broader concepts, and devise new ideas and solutions.

In this digital era, a teacher working in higher education institute has to understand difference between "learning about" and "learning to be" and implement the later for the effective learning outcome among the learners. Proper involvement of the learner ought to be ensured in the discipline which is meant for learning to be-i.e. if a learner is enrolled in teacher education programme he should have direct exposure of teaching skills. The digital periphery can be accommodating to learner for the content exploration to work out lessons in a digital form and teacher's role from technical to teaching point will be crucial.

Teachers have to make the available support structures and systems for them to develop skills like interactive learning, collaborative learning and independent learning among the students. The teachers' role expands to nurture critical thinking, creativity and scientific temper among the students to transform them into life-long learners and innovators.

Teachers working in Indian higher education system have to manage the technologies and facilities available for effective teaching-Virtual laboratories, e-learning resources from National Programme on Technology Enhanced Learning (NPTEL) and National Mission on Education through Information and Communication Technology (NME-ICT), open educational resources, mobile education, etc.

A teacher equipped with digital command can nurture critical thinking, creativity and scientific temper among the students to transform them into life-long learners and innovators. It's teacher's role to expose the learner to advanced level of knowledge and skills (blended learning, expert lectures, seminars, workshops etc. Teacher can play a pivotal role in preparing a complete repository comprising the details on the academic, personal and psycho-social support and guidance services (professional counselling/mentoring/academic advice) provided to students. Teacher ought to use e-library resources to augment the teaching-learning process. 
It's a vital function of techno-savvy teachers to empower and enable themselves as well as their learners for the use of various tools and technology for improved teaching-learning process. They should sharpen their skills in teaching learning methods/approaches compatible with digital technology. Content and knowledge management is a key knack for teacher to survive in digital environment. They have to select, develop, and enrich teaching-learning material in digital structure and with any-time anywhere mode. Now the teacher's role has changed with the advancement of technology, the assessment of the students' learning has transcended the four wall of class-room. As the learner gets information and knowledge through digital window; hence their assessment will have to be designed in that fashion only. Here teacher's role is to collaborate with students as well as other mentor and teachers of the world.

In this digital era, teachers' role has shifted from mere preacher to the manager of students social and emotions behaviours; mentor for their learning and over-all development as a balanced citizen; motivator for slow learner and a fast learner in digital environment. He has to keep watch on the time spent by learners for their proper time management which make certain that the learner utilize optimum e-recourse. He has to address social and emotional issues that affect learners' learning, and be ready to make changes when their learning stalls.

\section{CONCLUSION:}

Ultimately, we have to keep in mind that it is unnecessary and impossible to keep up all information in everyday life but always be ready to share and participate. Shah (2014) rightly stated that as the teacher and the textbook get replaced by these digital recourses of learning, there are many attempts that try and expand the information scope and repertoire of the teacher, firmly believing that installing smart boards and digitally connecting the classrooms is the solution. However, it is obvious to anybody with their ear on the ground that we will need to reevaluate the role of teacher, and construct our education systems, not so be pale imitations of older classrooms, as we see in the rise of the massively open online courseware. We don't need apps and hacks for learning, or gamified platforms, though they do help, what we need is an introspection into role of teacher, not competing with internet but helping students learn, think, reflect, and implement their knowledge, as they collaborate and contribute, while "learning on the internet”.

\section{REFERENCES:}

Ben Youssef, Adel; Dahmani, Mounir (2008). "The Impact of ICT on Student Performance in Higher Education: Direct Effects, Indirect Effects and Organizational Change”. In: "The Economics of E-learning" [online monograph]. Revista de Universidady Sociedad del Conocimiento(RUSC). Vol. 5, no. 1. UOC.

Retrieved from <http://www.uoc.edu/rusc/5/1/dt/eng/benyoussef_dahmani.pdf $>$ ISSN 1699-8154. 


\section{Redefining the Role of Teachers in the Digital Era}

Coming To Teaching In The 21st Century: A Research Study Conducted By The Galileo Educational Network.

Retrieved from http://www.galileo.org/research/publications/ctt.pdf

Lentell, H. (2003) 'The Importance of the Tutor in Open and Distance Learning', in A. Tait \& R. Mills (eds). Rethinking Learner Support in Distance Education, pp. 64-76. London: RoutledgeFalmer.

Lu J, Lu C, Yu CS, Yao JE 2014. Exploring factors associated with wireless internet via mobile technology acceptance in Mainland China. Communications of the IIMA, 3(1): 9.

Pedagogical Roles and Competencies of University Teachers Practicing in the E-Learning Environment. Retrieved from http://www.irrodl.org/index.php/irrodl/article/view/ $1477 / 2586$

Shah, N. (2014). The Future of classroom: the role of teachers needs a relook in digital era. Retrieved from http://indianexpress.com/article/lifestyle/the-future-classroom-the-roleof-teachers-needs-a-relook-in-digital-era/99/print/

The Digital Age: Changing Roles of Lecturers at a University of Technology in South Africa. Retrieved from http://www.krepublishers.com/02-Journals/JSS/JSS-42-0-000-15Web/JSS-42-1-2-15-Abst-PDF/JSS-42-1,2-165-15-1418-Odora-R-J/JSS-42-1,2-165-151418-Odora-R-J-Tx[18].pdf

The Role of Educators in the Digital Era. Retrieved from https://sites.psu.edu/ pul121edtec467/2014/02/15/the-role-of-educators-in-the-digital-era/

Timor, T. (2014). Teachers' Role in the Technological Era of the 21st Century, EDULEARN, 14 Proceedings, pp. 4322-4330.

Weinberger, A., Fischer, F., \& Mandl, H. (2002). Fostering individual transfer and knowledge convergence in text-based computer-mediated communication. In G. Stahl (Ed.), Computer support for collaborative learning: Foundations for a CSCL community. Proceedings of CSCL 2002. Mahwah, NJ: Lawrence Erlbaum.

Weller M, Anderson, T. (2013). Digital resilience in higher education. European Journal of Open, Distance and E-Learning, 16(1): 53.

Zhu, Chang. Teacher roles and adoption of educational technology in the Chinese context. Journal for educational research online 2 (2010) 2, S. 72-86 urn:nbn:de:0111-opus45769

http://www.pedocs.de/volltexte/2011/4576/pdf/JERO_2010_2_Zhu_Teacher _roles_and_adoption_of_educational_S72_D_A.pdf

How to cite this article: J Amin (2016), Redefining the Role of Teachers in the Digital Era, International Journal of Indian Psychology, Volume 3, Issue 3, No. 6, DIP: 18.01.101/20160303 